\title{
The Establisment of Caring Community Through TB Care Muhammadiyah at Puskesmas Tamansari TAsikmalaya City
}

\author{
Nina Pamela Sari ${ }^{*}{ }^{1}$, Asep Muksin ${ }^{2}$, Putri Nur Anjeli ${ }^{3}$, Haeva Firda Nisa ${ }^{4}$, Eri Nugraha ${ }^{5}$ \\ 1,2,3) Program Studi D3 Keperawatan, Fakultas IImu Kesehatan \\ Universitas Muhammadiyah Tasikmalaya \\ *Corresponding Author:ninapamelasari@gmail.com
}

\begin{abstract}
A bstrak
Tuberculosis is an infectious disease whose number is still increasing in Indonesia, especially in Mulyasari Village, Tamansari District, Tasikmalaya City. TB incidence in Tamansari as of November 2020 reached 58 people, 3 people died and 1 person experienced drug resistance. Muhammadiyah is an Islamic da'wah movement for amar ma'ruf nahi munkar whose one of its da'wah movements is concerned with social humanitarian movements in the health sector. One of the health services that continues to be developed by Muhammadiyah is service and counseling to the community about TB disease and socialization of the use of TB Comprehensive PMO guidelines which can improve the cognitive, affective and psychomotor abilities of TB PMO which have an impact on increasing public awareness of TB disease. This program is implemented through counseling to cadres, religious leaders and PMOs in the work area of the Tamansari Health Center about TB disease and socialization of the use of TB Comprehensive PMO guidelines. Tamansari Health Center consists of 4 sub-districts, namely Mulyasari village, Sukahurip village, Setyawargi village and Setyamulya village. The results of this community service are an increase in the knowledge of cadres, PMOs and religious leaders about TB control and the formation of the TB Care Muhammadiyah management where in each disctrict there are 4 Muhammadiyah branch managers who collaborate with the village cadre coordinator to participate in monitoring the treatment of TB patients in the Tamansari area.
\end{abstract}

\begin{tabular}{l}
\hline \multicolumn{1}{c}{ A r t i c l e I n f o } \\
\hline Article History: \\
Received 1 November 2021 \\
Revised 10 November 2021 \\
Accepted 20 November 2021 \\
Available online 15 January 2022 \\
Keywords: \\
tuberculosis, \\
Muhammadiyah, \\
observers. \\
\end{tabular}

\section{INTRODUCTION}

Muhammadiyah is an Islamic da'wah movement for amar ma'ruf nahyi munkar whose one of its da'wah movements is concerned with social humanitarian movements in the health sector. Muhammadiyah has always been active and active by providing health services in the midst of the community. One of the health services that continues to be developed by Muhammadiyah is service and counseling to the community about TB disease and socialization of the use of TB Comprehensive observers guidelines which can improve the cognitive, affective and psychomotor abilities of observers TB which have an impact on increasing public awareness of TB disease in collaboration with various public health institutions. Guidelines for Drug Swallowing Supervisors (observers) for Tuberculosis Patients currently in Indonesia do not yet have a uniform form to be applied in all regions in Indonesia. Meanwhile, the observers duties have been stated in the government regulation, Regulation of the Minister of Health of 
the Republic of Indonesia number 67 of 2016 concerning Tuberculosis Management. So far, the observers in carrying out its duties is still verbal, without neat documentation, or just checking the dates on the calendar. The use of the observers guidelines used is based on the results of research that the author did previously with the results of the Comprehensive Guidelines for TB PMOs which have been issued by Intellectual Property Rights (HKI) with number EC00201813562 dated May 23, 2018, regarding the Comprehensive Guidelines for TB PMOs. ${ }^{2,5,7}$

The problems that occur today are that observers TB understanding of their duties is not optimal, the position of observers in the family becomes less dominant when the TB patient is the husband while the observer is the patient's wife, the limited number of health workers in health center, only one TB programmer, one health care nurse manages, Tamansari district. The problems above can have an impact on the lack of family care that has an impact on the community towards TB patients, the emergence of stigma against TB patients. This problem can have an impact on less than optimal supervision of TB patients undergoing treatment, this will result in an increasing number of TB. According to WHO, 1 TB patient can infect 15 people around him, the emergence of stigma for TB patients, the lack of public care for TB patients. 2,7

The solution offered to deal with these problems is through the establishment of a TB Care Community in Tamansari District which is the working area of the Tamansari Health Center. This program is implemented through counseling to cadres, religious leaders and observers in the work area of the Tamansari Health Center about TB disease and socialization of the use of TB Comprehensive observers guidelines which can improve the TB observers cognitive, affective and psychomotor abilities which have an impact on increasing public awareness of TB disease.

\section{METHOD OF IMPLEMENTATION}

The stages of implementing community service regarding the formation of a Tuberculosis Care Society through the use of the TB observers Guidelines at the Tamansari Health Center are as follows: 1. Cadre Gathering: The first stage together with the TB puskesmas programmer is to collect active cadres and religious leaders in each district in the target area of the Tamansari Health Center 2. TB Counseling and Dissemination of TB observers Comprehensive Guidelines for cadres, observers accompanied by religious leaders: The second stage is TB counseling, dissemination of observers TB Comprehensive Guidelines for cadres, observers accompanied by religious leaders or religious leaders with Muhammadiyah branch managers 3. Assistance in the Implementation of the observers TB Comprehensive Guidelines: The third stage is to assist observers together with cadres, religious leaders or Muhammadiyah branch managers in carrying outobservers duties using the observers TB Comprehensive Guidelines 4. Evaluation $=$ The fourth stage is to evaluate the achievement of the implementation of observers tasks in forming a TB care community.

\section{RESULTS AND DISCUSSIONS}

The results of this community service which was carried out on November 30, 2021, obtained an agreement to form a Muhammadiyah TB care team in each districts that would cooperate with TB observers in supervising and supporting TB patients in carrying out their treatment. TB treatment really needs support from the surrounding environment, with the support of observers TB ${ }^{1,3,5}$ using the TB guidelines compiled by the author ${ }^{5}$ and strengthened from a religious perspective, especially with the Tb Care Muhammadiyah team. treatment until 
healed and complete. ${ }^{4.6}$

\section{CONCLUSIONS AND SUGGESTIONS}

Tuberculosis is one of the infectious infectious diseases that continues to increase, so it is important for TB patients to understand in carrying out their treatment programs regularly until they are cured ${ }^{1,2}$, moreover, this disease is very contagious in the surrounding environment so patients must be able to undergo treatment completely until recovered. Tuberculosis if treated regularly and disciplined can be completely cured. The observers are also important in assisting TB patients to undergo the treatment process on a regular basis. Through this community service activity, by increasing the role of observers through the approach of religious leaders, so that a TB care community is formed which is facilitated by TB Care Muhammadiyah.

\section{ACKNOWLEDGMENTS}

Our gratitude goes to the Universitas Muhammadiyah Tasikmalaya and LPPM Umtas who have given us the opportunity to be able to carry out this community service and have also facilitated us financially so that this activity can be carried out properly. We also thank Tamansari Health Care Tasikmalaya City for allowing us to carry out this activity.

\section{REFERENCES}

(1) GS Nugraha, YR Romli, NP Sari, HUBUNGAN FAKTOR PELAKSANAAN TUGAS PENGAWAS MENELAN OBAT (PMO) DENGAN KEJADIAN DROP OUT (DO) PENGOBATAN TUBERCULOSIS (TB) Healthcare Nursing Journal, 2019

(2) Kementrian Kesehatan Republik Indonesia, (2016). Peraturan Menteri Kesehatan Republik Indonesia nomor 67 tahun 2016 tentang Penanggulangan Tuberkulosis.

(3) Nina Pamela Sari, Neti Juniarti, \& Desy Indra Yani. (2020). DEVELOPMENT OF GUIDELINES FOR OBSERVER TUBERCULOSIS PATIENTS IN TASIKMALAYA CITY, INDONESIA. Malaysian Journal of Medical Research (MJMR), 4(3), 15-25. https://doi.org/10.31674/mjmr.2020.v04i03.004

(4) Nina Pamela Sari. (2018). THE INFLUENCE OF GUIDELINES FOR TB OBSERVER TASK IN TAMANSARI HEALTH CENTER TASIKMALAYA CITY INDONESIA. Malaysian Journal of Medical Research (MJMR), 2(4), 32-38. https://doi.org/10.31674/mjmr.2018.v02i04.004

(5) Sari, N.,P. (2017). Pedoman Komprehensif PMO TB; Hak Kekayaan Intelektual, diunduh dari:

hakcipta.dgip.go.id/index.php/c?code=tbXIOnV61ugmAKKWiibufuzw12osbmZNOR6 wC\%2BzQCQ8\%3D

(6) Sari, N., P. (2020) Tb Care Muhammadiyah Bentuk Masyarakat Peduli Tb Tamansari | kapol.id

(7) World Health Organization. (2018). Tuberculosis. http://www.who.int/news-room/factsheets/detail/tuberculosis 